\title{
Estimates of Prey Consumption and Trophic Impacts of Cetaceans in the USA Northeast Continental Shelf Ecosystem
}

\author{
Robert D. Kenney \\ Graduate School of Oceanography, University of Rhode Island \\ Bay Campus Box 41, Narragansett, Rhode Island 02882, USA \\ Gerald P. Scott \\ National Marine Fisheries Service, Southeast Fisheries Science Center \\ 75 Virginia Beach Drive, Miami, Florida 33149, USA \\ Thomas J. Thompson \\ College of Health, Florida International University \\ North Miami, Florida 33181, USA \\ and \\ Howard E. Winn ${ }^{1}$ \\ Graduate School of Oceanography, University of Rhode Island \\ Narragansett, Rhode Island 02882, USA
}

\begin{abstract}
Whales, dolphins and porpoises are significant consumers of prey resources in the USA Northeast Shelf marine ecosystem to a far greater extent than was realized two decades ago. Seasonal estimates of the consumption of finfish, squid and zooplankton by cetaceans were calculated for four regions of the Northeast Shelf system defined as Gulf of Maine, Georges Bank, Southern New England and Mid-Atlantic Bight. Estimates were based on seasonal cetacean abundance using standard mammalian metabolic models scaled as appropriate for assimilation, activity and migratory fasting. Estimates were made of mean body mass and proportion of the diet comprised of each of the three main prey types. Cetaceans of the Northeast Shelf were found to consume nearly 1.9 million tons annually, including about 1.3 million tons of fish, 337000 tons of squid and 244000 tons of zooplankton. Their predation on fish and squid exceeded tonnages harvested in the commercial fishing industry. Consumption estimates of fish dominated in most regions and seasons, primarily because of the widespread distribution and high relative abundance of large piscivorous fin whales, and secondarily due to the presence of humpback and minke whales and some of the smaller odontocetes. Zooplankton consumption, principally by right and sei whales and secondarily by other mysticetes, was significant in some seasons in the Gulf of Maine and Georges Bank regions. An assemblage which included a variety of teuthivorous odontocete species inhabiting the shelf break vicinity consumed substantial quantities of squid in all regions except the Gulf of Maine. Using a simple five-level trophic model and $10 \%$ estimated trophic transfer efficiency, the estimates implied that a significant fraction of the total net primary production, ranging from $11.7 \%$ in the Mid-Atlantic Bight to $20.4 \%$ in the Gulf of Maine, was required to the support cetacean apex predation.
\end{abstract}

Key words: cetaceans, ecosystems, food/feeding, Georges Bank, Gulf of Maine, Mid-Atlantic Bight, New England area, trophic relationships

\footnotetext{
${ }^{1}$ Deceased 13 August 1995
} 


\section{Introduction}

The ecological roles of cetaceans in the trophic dynamics of marine ecosystems have been relatively poorly known until recently. For the continental shelf waters off the northeastern United States (the "Northeast Shelf"), it was commonly assumed that cetaceans were relatively unimportant consumers in the regional trophic system (e.g. Cohen et al., 1982; Sissenwine et al., 1984a). This assumption was likely based, at least in part, on a lack of information on the cetaceans. Prior to the Cetacean and Turtle Assessment Program (CETAP), conducted at the University of Rhode Island in 1979-82, there were very few reliable data on the species composition, abundance, distribution and seasonality of the cetacean community of the Northeast Shelf. The CETAP studies resulted in over 10000 sightings of whales and dolphins (CETAP, 1982), enabling for the first time a quantitative assessment of their ecological impacts, i.e. levels of prey consumption in the Northeast Shelf ecosystem.

The Northeast Shelf, encompassing the continental shelf waters between North Carolina and Nova Scotia, is one of 49 defined Large Marine Ecosystems (LME) around the world (Sherman and Alexander, 1986, 1989; Sherman et al., 1990, 1991, 1993, 1996). The marine environment of the Northeast Shelf is both physically and biological heterogeneous (Sherman et al., 1988; 1996), ranging from the relatively uniform bottom relief in the southern portions to the complex bathymetry of Georges Bank and the Gulf of Maine to the north. The area encompasses a latitudinal range that includes both temperate and boreal water masses, and includes a number of complex features such as shoals, banks, basins and canyons. Nevertheless, patterns in the hydrography and biological communities in different parts of the Northeast Shelf enable subdivision into four more or less natural regions: the Gulf of Maine (GOM), Georges Bank (GBK), Southern New England (SNE) and the Mid-Atlantic Bight (MAB) (Fig. 1).

Whales, dolphins and porpoises are all carnivores, and they have few predators, so they function as apex predators in many marine ecosystems. Their diets include a wide variety of prey species, including pelagic, demersal and benthic fishes, euphausiids ("krill"), copepods and other crustacean zooplankton, shrimp, crabs, squid, octopods, birds and other marine mammals (Nemoto, 1970; Matthews, 1978; Gaskin, 1982; Evans, 1987).

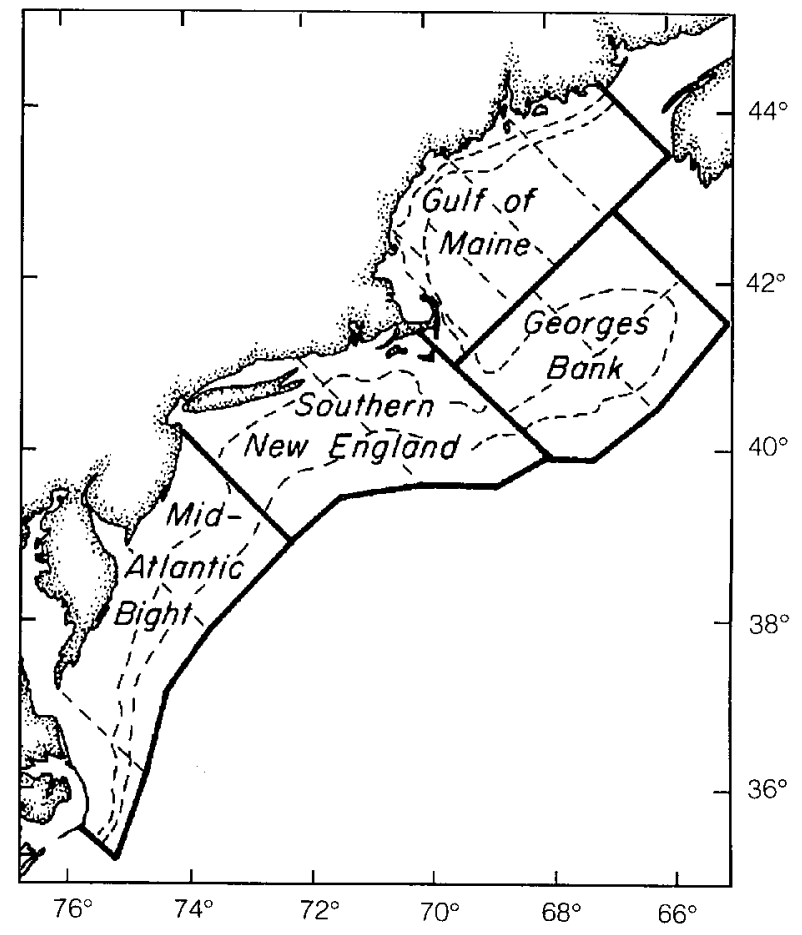

Fig. 1. The USA Northeast Shelf study area, showing the boundaries of the four regions defined for this study. The dashed lines show the individual CETAP aerial survey blocks, which numbered 35 in all. The area boundaries also indicate the bathymetry based on the 20 fathom $(37 \mathrm{~m}$ ) and 50 fathom $(91 \mathrm{~m})$ isobaths used in defining the individual survey blocks, and the outer edge of the study area approximately at the $2000 \mathrm{~m}$ is obath.

Therefore they feed at different levels of marine food webs. Some species are specialists, feeding exclusively on a single prey type, while others are generalists with broader preferences. Nevertheless, one can classify the prey species of North Atlantic cetaceans into three broad categories - fish, squid (including other cephalopods) and zooplankton.

Many of the species consumed by cetaceans are likely to be either important target species of commercial fisheries, or linked to such species through the food web. Thus, predation by cetaceans is one factor which should be considered in multi-species fishery management models. In this paper an attempt is made to estimate seasonal and total prey consumption by cetaceans within the major regions of the Northeast Shelf. The objective here is not to test statistical hypotheses but to derive useful and realistic estimates of the impacts of cetaceans on 
one marine ecosystem. It is also hoped that the results can serve as a useful comprehensive source of information for future understanding and management of the Northeast Shelf marine ecosystem.

\section{Methods}

The starting point was abundance estimates derived from the CETAP surveys, which were adjusted for several factors using all available data to produce what we feel are the most ecologically realistic estimates of abundance from the perspective of the entire community, not the most precise single-species estimates. At each step in the calculations where there was a need to choose between alternative values, our default choice was the more conservative option (i.e. that resulting in lower estimates) where one was not clearly preferable for biologically supportable reasons. We have intentionally not included estimates of statistical variability in our results. Since the initial abundance estimates are essentially the only input data with variances available, variances at any step in the results would simply be those initial values propagated through the model.

\section{Study area}

The CETAP study area was defined as the waters of the continental shelf from the shoreline to approximately the 2000 -meter isobath from Cape Hatteras, North Carolina to approximately the northern extent of USA jurisdiction (before the establishment of the Hague Line by the World Court) in the Gulf of Maine (Fig. 1). For this paper, the study area was divided into four regions by combining the CETAP aerial survey blocks to most closely approximate the regions defined by the National Marine Fisheries Service (NMFS) based on geography, bathymetry, hydrography and seasonal patterns of productivity and distribution, abundance and dominance within the plankton community (Sherman, 1980, 1986; Sherman et al., 1982, 1988). The areas of the four regions, (with the percentage of the total study area in parentheses) were: GOM - $72054 \mathrm{~km}^{2}(25.9 \%), \mathrm{GBK}-69004 \mathrm{~km}^{2}$ $(24.8 \%), \mathrm{SNE}-69410 \mathrm{~km}^{2}(24.9 \%)$ and MAB $67891 \mathrm{~km}^{2}(24.4 \%)$.

\section{Abundance estimates}

Kenney et al. (1985) estimated seasonal abundances for each species in each survey block (the small areas shown by dashed lines in Fig. 1), based on data from the CETAP aerial surveys (CETAP, 1982). They defined seasons based on standard cal- endar conventions. For this paper, those seasonal estimates were summed for each species across each of the four regions, resulting in an estimate of the total abundance of each species within each region and season.

Eighteen species of cetaceans were sighted during the CETAP aerial surveys (Table 1). Three categories - beaked whale, pilot whale and spotted dolphin - included two or more species within one genus, which were impossible to differentiate from aerial surveys and therefore combined. There were also a number of other categories of unidentified sightings, which in some cases represented significant numbers of animals in the estimates summed from Kenney et al. (1985). The estimated abundance of each unidentified category was partitioned among those species which could be included based on the relative proportions of their estimated abundances within that region and season, beginning with the narrowest categories (e.g. "fin or sei whale") and ending with the broadest (e.g. "unidentified large whale"). Some subjective judgments based on the complete CETAP sighting records were used in the partitioning. The abundance estimates were based on only a subset of the aerial surveys, but there were several other sources of sighting data. Thus there were a number of species where there were no abundance estimates for a region and season even though there were sightings, especially for those species which were uncommon or difficult to identify. The sighting maps in CETAP (1982) were visually examined to compare relative numbers of sightings of species with and without estimates. If there were only one or two sightings of a species with no abundance estimate for a region/ season, that species was ignored. If there were more sightings, but still substantially fewer than for species with estimates for that region/season, then 5\% of the appropriate unidentified categories was assigned to that species. Finally, if the number of sightings of a species with no estimate appeared to be more than about a quarter of species with estimates, it was assigned $10 \%$ of the unidentified individuals. For example, both common dolphins and sei whales were infrequent in summer in GBK and were not sighted on census tracks during aerial surveys. However the complete CETAP sighting data showed both species to be regularly present (CETAP, 1982), therefore $5 \%$ of the unidentified dolphins were counted as common dolphins, and $5 \%$ of the unidentified whales as sei whales. In another example, no sperm whales were sighted in GBK in the autumn during aerial surveys, but they were 
relatively frequent in sightings from other sources, so $10 \%$ of the 43 unidentified large whales were counted as sperm whales.

For minke whales and harbor porpoises, which both tend to be solitary and inconspicuous, aerial surveys very likely seriously underestimate abundance (Kraus et al., 1983; Barlow et al., 1988; Palka, 1995). However, there are more recent estimates for both species for part of the CETAP study area from shipboard surveys for harbor porpoise conducted by the National Marine Fisheries Service (NMFS) (Blaylock et al., 1995; Palka, 1995). The NMFS data were compared to ours for the same area and season to derive approximate values for the aerial survey bias in the CETAP data for these two species, which were then applied to the other areas and seasons. The NMFS weighted-average estimated abundances of harbor porpoises and minke whales in the northern GOM and lower Bay of Fundy for summer 1991 and 1992 were 47200 and 2650 , respectively. The areas were not identical, however. Estimating visually, about $40 \%$ of the NMFS survey area was within our GOM region, and $40 \%$ of their total estimates would be 18880 harbor porpoises and 1060 minke whales. Those estimates were 9.3 and 10.6 times our summed GOM/ summer estimates of 2036 harbor porpoises and 100 minke whales, respectively, therefore a factor of 9.3 was used to adjust all of our harbor porpoise estimates for the aerial survey bias, and 10.6 for the minke whale estimates. These factors were considered conservative, since the NMFS surveys only covered about half of our GOM region.

\section{Dive time corrections}

It is recognized that for species which spend a large proportion of their time submerged, surveys from fast-moving aircraft will miss many individuals or groups while they are submerged. We used correction factors derived from data on the relative proportions of time spent at the surface and submerged (CETAP, 1982) for fin (4.846), humpback (3.645), and right whales (2.997). All other abundance estimates for large and medium-sized whales were also scaled for diving. Sei whales and minke whales belong to the same family as fins and humpbacks and are behaviorally similar, thus to be conservative the humpback correction factor was used. Also, the conservative factor for fin whale was used for sperm and beaked whales, that are known to dive for longer periods than fin whales (Evans, 1987; Jefferson et al., 1993). Lacking any data for the smaller and shorter-diving odontocetes, those abundances were not scaled for diving.

\section{Standing stock}

The total cetacean standing stock in each region and season was estimated by multiplying abundance by average body weight (from Kenney et al., 1985; Table 1), which then was summed across all species. Biomass densities were calculated for each region and season by dividing standing stocks by the area of the region.

\section{Basal metabolic rate}

The basal metabolic rate (BMR, in $\mathrm{kcal} /$ day) of one individual was estimated for each species according to the standard mammalian metabolic model of Kleiber (1975):

$$
B M R=70 W^{0.75}
$$

where $W$ is the body weight in $\mathrm{kg}$. For each species, the average body weights reported by Kenney et al. (1985; Table 1) were used.

\section{Prey consumption rate}

BMR was converted to consumption rate (kcal per day) by multiplying by factors to account for assimilation efficiency, active metabolism and fasting during migration. Assimilation efficiency was assumed to be $80 \%$ following Lockyer (1978; $1981 \mathrm{a}, \mathrm{b})$, resulting in a multiplication factor of 1.25. Active metabolism in cetaceans has been estimated at approximately 2 to 5 times BMR (Hinga, 1979; Lockyer, 1981b; Kenney et al., 1986). A value of 2.5 times BMR was chosen at near the bottom of that range in order to scale for active metabolism. Animals which do not feed, or feed at significantly lower rates, during migration and/or on their wintering grounds must feed at a higher rate during the rest of the year to compensate (Mackintosh, 1966; Brodie, 1975; Matthews, 1978; Lockyer, 1981b; Evans, 1987). Since for most species, there is very little information on their distribution and behavior during the winter, a relatively low value was used here at 1.2 times. This factor was applied only to the baleen whales, and only during spring, summer, and autumn.

Daily consumption rate was converted to seasonal values of prey biomass consumed by multiplying by the average number of days in a season (91.3), by the proportion of the diet comprised of 
TABLE 1. Cetacean species of the USA Northeast Shelf with estimated average body weights and dietary composition used in this study.

\begin{tabular}{|c|c|c|c|c|}
\hline \multirow[b]{2}{*}{ Species } & \multirow[b]{2}{*}{ Weight (kg) } & \multicolumn{3}{|c|}{ Diet Composition (\%) } \\
\hline & & Fish & Squid & Zooplankton \\
\hline \multicolumn{5}{|l|}{ Mysticetes: } \\
\hline Right whale, Eubalaena glacialis & 40000 & - & - & 100 \\
\hline Fin whale, Balaenoptera physalus & 30000 & 90 & - & 10 \\
\hline Sei whale, Balaenoptera borealis & 13000 & - & - & 100 \\
\hline Minke whale, Balaenoptera acutorostrata & 4500 & 95 & - & 5 \\
\hline Humpback whale, Megaptera novaeangliae & 25000 & 95 & - & 5 \\
\hline \multicolumn{5}{|l|}{ Odontocetes: } \\
\hline Sperm whale, Physeter macrocephalus & 20000 & 20 & 80 & - \\
\hline Bottlenose whale, Hyperoodon ampullatus & 4700 & 5 & 95 & - \\
\hline Goose-beaked whale, Ziphius cavirostris & 1900 & - & 100 & - \\
\hline Beaked whale, Mesoplodon spp. ${ }^{1}$ & 1200 & - & 100 & - \\
\hline Pilot whale, Globicephala spp. ${ }^{2}$ & 850 & 10 & 90 & - \\
\hline Risso's dolphin, Grampus griseus & 340 & - & 100 & - \\
\hline Bottlenose dolphin, Tursiops truncatus & 150 & 100 & - & - \\
\hline White-sided dolphin, Lagenorhynchus acutus & 120 & 90 & 10 & - \\
\hline Common dolphin, Delphinus delphis & 65 & 85 & 15 & - \\
\hline Striped dolphin, Stenella coeruleoalba & 55 & 40 & 60 & - \\
\hline Spotted dolphin, Stenella spp. ${ }^{3}$ & 50 & 20 & 80 & - \\
\hline Spinner dolphin, Stenella longirostris & 50 & 20 & 80 & - \\
\hline Harbor porpoise, Phocoena phocoena & 45 & 95 & 5 & - \\
\hline
\end{tabular}

1 Includes four species - M. mirus, M. densirostris, M. europaeus, M. bidens

2 Includes two species - G. melas, G. macrorhynchus

3 Includes two species - S. attenuata, S. plagiodon

fish, squid and zooplankton and by an energy density value for each prey type. The dietary proportions (Table 1) were from Kenney et al. (1985), with one exception. The diet of pilot whales was changed from $100 \%$ squid to $90 \%$ squid and $10 \%$ fish based on recent data showing significant interactions between pilot whales and the offshore non-USA and joint-venture midwater mackerel fishery which included samples of pilot whale stomachs containing mackerel (Waring et al., 1990; Overholtz and Waring, 1991; Fairfield et al., 1993). The energy content of fish and zooplankton was assumed to be $1 \mathrm{kcal}$ per $\mathrm{g}$ wet weight (Clark and Prince, 1980; Sissenwine et al., 1984a), while the energy content of squid was assumed to be $0.83 \mathrm{kcal}$ per g (Croxall and Prince, 1982). Consumption estimates were then summed across all species for each region and season.

\section{Primary production required}

The total amount of primary production required to support the cetaceans of a region was es- timated using a simplified model food chain with five trophic levels. The transfer efficiency from one trophic level to the next was assumed to be $10 \%$, following Pauly and Christensen (1995). The general relationship was that the total amount of primary production required was calculated from the prey consumption rate using a factor of $10^{\mathrm{n}}$, where $\mathrm{n}$ is the number of trophic steps from the phytoplankton or the first trophic level to the given prey type. The trophic level (TL) values reported by Pauly and Christensen (1995) for non-tropical continental shelf systems were used: $\mathrm{TL}=2.0$ for herbivorous zooplankton, $\mathrm{TL}=3.0$ for schooling planktivorous fishes (e.g. herring or sand lance), and $T L=3.2$ for squid. Primary production required was converted from energy to carbon by $13.3 \mathrm{kcal}$ per g C (Platt, 1969). The resulting values were compared to published estimates of total primary production for the Northeast Shelf in order to estimate what proportion of the total phytoplankton production was eventually transferred up the food chain to whales and dolphins. 


\section{Results}

\section{Abundance and standing stock}

Eighteen species of cetaceans were observed during the CETAP aerial line-transect surveys, and resulting estimates of abundance are given in Table 2. Those estimates tended to have large variances; with coefficients of variation ranging from $69 \%$ to $356 \%($ median $=163 \%)($ Kenney et al., 1985$)$. Minke whales were the most abundant of the baleen whales, with over 13000 in the entire study area in the spring, followed in descending order by fin, sei, humpback and right whales. The most abundant odontocetes were harbor porpoises, with a peak population in spring of over 49 000. This was fol- lowed by common dolphins and white-sided dolphins, both in excess of 40000 , and several other dolphin species with populations estimated at 11-16 000. The total cetacean population of the Northeast Shelf was over 210000 animals. Sixteen species were most abundant during the spring and/ or summer seasons; the two exceptions were common dolphins with peak abundance during the winter, and white-sided dolphins with peak abundance in the autumn.

Peak cetacean standing stock in the Northeast Shelf ecosystem was in the spring at over 320000 tons, equivalent to a biomass density of $1166 \mathrm{~kg} /$ $\mathrm{km}^{2}$, followed by summer, autumn and winter

TABLE 2. Seasonal estimates of abundance for eighteen cetacean species for the USA Northeast Shelf, and in its four regions (see text for definitions).

\begin{tabular}{|c|c|c|c|c|c|c|}
\hline \multirow[b]{2}{*}{ Species } & \multirow[b]{2}{*}{ Season } & \multicolumn{4}{|c|}{ Region } & \multirow{2}{*}{$\begin{array}{c}\text { Northeast } \\
\text { Shelf } \\
\text { Total }\end{array}$} \\
\hline & & GOM & GBK & SNE & MAB & \\
\hline \multirow[t]{4}{*}{ Right whale } & Winter & - & - & - & - & - \\
\hline & Spring & 233 & 128 & 32 & - & 393 \\
\hline & Summer & 251 & - & - & - & 251 \\
\hline & Autumn & - & - & - & - & - \\
\hline \multirow[t]{4}{*}{ Fin whale } & Winter & - & 596 & 668 & 542 & 1806 \\
\hline & Spring & 1793 & 1381 & 794 & 1066 & 5034 \\
\hline & Summer & 3329 & 852 & 1759 & 135 & 6075 \\
\hline & Autumn & 1075 & 188 & 373 & 358 & 1994 \\
\hline \multirow[t]{4}{*}{ Sei whale } & Winter & - & 616 & - & - & 616 \\
\hline & Spring & 174 & 1982 & - & - & 2156 \\
\hline & Summer & 7 & 284 & - & - & 291 \\
\hline & Autumn & - & 524 & - & - & 524 \\
\hline \multirow[t]{4}{*}{ Minke whale } & Winter & - & - & 425 & - & 425 \\
\hline & Spring & 3129 & 6800 & 3361 & 193 & 13483 \\
\hline & Summer & 3864 & 425 & - & 656 & 4945 \\
\hline & Autumn & 3709 & - & - & - & 3709 \\
\hline \multirow[t]{4}{*}{ Humpback whale } & Winter & - & - & - & - & - \\
\hline & Spring & 273 & 156 & 47 & - & 476 \\
\hline & Summer & 663 & 40 & - & - & 703 \\
\hline & Autumn & 47 & 273 & - & - & 320 \\
\hline \multirow[t]{4}{*}{ Sperm whale } & Winter & - & 184 & 33 & 503 & 720 \\
\hline & Spring & - & 164 & 290 & 1187 & 1641 \\
\hline & Summer & - & 503 & 411 & 387 & 1301 \\
\hline & Autumn & - & 19 & - & 300 & 319 \\
\hline \multirow[t]{4}{*}{ Bottlenose whale } & Winter & - & - & - & - & - \\
\hline & Spring & - & 29 & - & 77 & 106 \\
\hline & Summer & - & - & - & - & - \\
\hline & Autumn & - & - & - & - & - \\
\hline
\end{tabular}


TABLE 2. (Continued). Seasonal estimates of abundance for eighteen cetacean species for the USA Northeast Shelf, and in its four regions (see text for definitions).

\begin{tabular}{|c|c|c|c|c|c|c|}
\hline \multirow[b]{2}{*}{ Species } & \multirow[b]{2}{*}{ Season } & \multicolumn{4}{|c|}{ Region } & \multirow{2}{*}{$\begin{array}{c}\text { Northeast } \\
\text { Shelf } \\
\text { Total }\end{array}$} \\
\hline & & GOM & GBK & SNE & MAB & \\
\hline \multirow[t]{4}{*}{ Goose-beaked whale } & Winter & - & - & - & - & - \\
\hline & Spring & - & - & 14 & 402 & 416 \\
\hline & Summer & - & - & 218 & 43 & 261 \\
\hline & Autumn & - & - & - & - & - \\
\hline \multirow[t]{4}{*}{ Beaked whale } & Winter & - & - & - & - & - \\
\hline & Spring & - & 533 & 111 & 121 & 765 \\
\hline & Summer & - & 499 & 305 & 135 & 939 \\
\hline & Autumn & - & 271 & - & - & 271 \\
\hline \multirow[t]{4}{*}{ Pilot whale } & Winter & - & 974 & 955 & 304 & 2233 \\
\hline & Spring & 438 & 6284 & 2973 & 1779 & 11474 \\
\hline & Summer & - & 4890 & 893 & 3056 & 8839 \\
\hline & Autumn & 225 & 543 & 2516 & 6527 & 9811 \\
\hline \multirow[t]{4}{*}{ Risso's Dolphin } & Winter & - & - & 28 & 777 & 805 \\
\hline & Spring & - & 345 & 1937 & 2649 & 4931 \\
\hline & Summer & - & 1872 & 6794 & 3168 & 11834 \\
\hline & Autumn & - & 3089 & 12 & 2725 & 5826 \\
\hline \multirow[t]{4}{*}{ Bottlenose Dolphin } & Winter & - & 1511 & 827 & 774 & 3112 \\
\hline & Spring & - & 2488 & 4685 & 3982 & 11155 \\
\hline & Summer & - & 3670 & 3497 & 4902 & 12069 \\
\hline & Autumn & - & 573 & 333 & 4809 & 5715 \\
\hline \multirow[t]{4}{*}{ White-sided Dolphin } & Winter & 7353 & 4957 & 37 & - & 12347 \\
\hline & Spring & 11093 & 27094 & 1703 & - & 39890 \\
\hline & Summer & 27029 & 10987 & - & - & 38016 \\
\hline & Autumn & 25474 & 16545 & 4 & - & 42023 \\
\hline \multirow[t]{4}{*}{ Common Dolphin } & Winter & 1052 & 10775 & 22714 & 10562 & 45103 \\
\hline & Spring & 40 & 5395 & 5543 & 8100 & 19078 \\
\hline & Summer & 198 & 633 & 1411 & 1959 & 4201 \\
\hline & Autumn & - & 16182 & 12473 & 2010 & 30665 \\
\hline \multirow[t]{4}{*}{ Striped Dolphin } & Winter & - & - & 4554 & 1937 & 6491 \\
\hline & Spring & - & 1482 & 2571 & 7972 & 12025 \\
\hline & Summer & - & 3120 & 5203 & 7997 & 16320 \\
\hline & Autumn & - & 5962 & 786 & 6734 & 13482 \\
\hline \multirow[t]{4}{*}{ Spotted Dolphin } & Winter & - & - & 482 & 107 & 589 \\
\hline & Spring & - & - & 901 & 1074 & 1975 \\
\hline & Summer & - & 235 & 870 & 1336 & 2441 \\
\hline & Autumn & - & 755 & 131 & 799 & 1685 \\
\hline \multirow[t]{4}{*}{ Spinner Dolphin } & Winter & - & - & - & - & - \\
\hline & Spring & - & - & - & 302 & 302 \\
\hline & Summer & - & - & 128 & 69 & 197 \\
\hline & Autumn & - & - & - & - & - \\
\hline \multirow{4}{*}{ Harbor Porpoise } & Winter & 1841 & 1209 & - & - & 3050 \\
\hline & Spring & 29481 & 17391 & 2548 & - & 49420 \\
\hline & Summer & 18934 & - & - & - & 18934 \\
\hline & Autumn & 548 & - & - & - & 548 \\
\hline
\end{tabular}


(Table 3). Two regions, GBK and MAB, had peak standing stocks during the spring, while the other two, GOM and SNE, had maxima during the summer. Both GOM and GBK showed very strong seasonal patterns, high during the warm part of the year and low during the colder seasons. The maximum regional cetacean standing stock was in GOM/ spring at 148072 tons or $2055 \mathrm{~kg} / \mathrm{km}^{2}$. SNE and MAB exhibited maximum densities less than half the level of the two northern regions, and less variation between seasons.
In terms of the biomass of individual species within the Northeast Shelf study area (Table 4), fin whales were the dominant cetaceans in all seasons, representing $46-64 \%$ of the total standing stock $($ mean $=56.2 \%)$. Other species which comprised large proportions of the total cetacean standing stock in more than one season included minke whales, sperm whales, and sei whales. A total of six species comprised at least $5 \%$ of the total standing stock in at least one season, including only one small odontocete (Table 4).

TABLE 3. Standing stock (tons) and biomass densities ( $\mathrm{kg}$ per $\mathrm{km}^{2}$, in parentheses) of cetaceans in the USA Northeast Shelf ecosystem and in its four regions (see text for definitions).

\begin{tabular}{|c|c|c|c|c|}
\hline \multirow{3}{*}{$\frac{\text { Region }}{\text { GOM }}$} & \multicolumn{4}{|c|}{ Season } \\
\hline & Winter & Spring & Summer & Autumn \\
\hline & $1034 \quad(14)$ & 89310 (1 239) & $148072(2055)$ & 53388 (741) \\
\hline GBK & $31972(463)$ & $121170(1756)$ & $49710 \quad(720)$ & $24983(362)$ \\
\hline SNE & $25313(365)$ & $52113 \quad(751)$ & 65792 & 14244 (205) \\
\hline MAB & 27757 (409) & $61903 \quad$ (912) & $20033 \quad$ (295) & 24477 (361) \\
\hline Northeast Shelf & 86076 (309) & $324496(1 \quad 166)$ & 283787 (1 019$)$ & 117092 \\
\hline
\end{tabular}

TABLE 4. Dominant cetacean species of the USA Northeast Shelf and its component regions (see text for definitions); those comprising more than five percent of the cetacean standing stock.

\begin{tabular}{|c|c|c|}
\hline Region & Season & Dominant Species (\% of total standing stock) \\
\hline GOM & $\begin{array}{l}\text { Winter } \\
\text { Spring } \\
\text { Summer } \\
\text { Autumn }\end{array}$ & $\begin{array}{l}\text { White-sided dolphin }(85.3) \text {, Harbor porpoise }(8.0) \text {, Common dolphin }(6.6) \\
\text { Fin whale }(60.2) \text {, Minke whale }(15.8) \text {, Right whale }(10.4) \text {, Humpback whale }(7.6) \\
\text { Fin whale }(67.7) \text {, Minke whale }(11.7) \text {, Humpback whale }(11.2) \text {, Right whale }(6.8) \\
\text { Fin whale }(60.4) \text {, Minke whale }(31.3) \text {, White-sided dolphin }(5.7)\end{array}$ \\
\hline GBK & $\begin{array}{l}\text { Winter } \\
\text { Spring } \\
\text { Summer } \\
\text { Autumn }\end{array}$ & $\begin{array}{l}\text { Fin whale }(55.9) \text {, Sei whale }(25.0) \text {, Sperm whale }(11.5) \\
\text { Fin whale }(34.2) \text {, Minke whale }(25.3) \text {, Sei whale }(21.3) \\
\text { Fin whale }(51.4) \text {, Sperm whale }(20.2) \text {, Pilot whale }(8.4) \text {, Sei whale }(7.4) \\
\text { Humpback whale }(27.3) \text {, Sei whale }(27.3) \text {, Fin whale }(22.6) \text {, White-sided dolphin }(7.9)\end{array}$ \\
\hline SNE & $\begin{array}{l}\text { Winter } \\
\text { Spring } \\
\text { Summer } \\
\text { Autumn }\end{array}$ & $\begin{array}{l}\text { Fin whale }(79.2) \text {, Minke whale }(7.6) \text {, Common dolphin }(5.8) \\
\text { Fin whale }(45.7) \text {, Minke whale }(29.0) \text {, Sperm whale }(11.1) \\
\text { Fin whale }(80.2) \text {, Sperm whale }(12.5) \\
\text { Fin whale }(78.6) \text {, Pilot whale }(15.0) \text {, Common dolphin }(5.7)\end{array}$ \\
\hline MAB & $\begin{array}{l}\text { Winter } \\
\text { Spring } \\
\text { Summer } \\
\text { Autumn }\end{array}$ & $\begin{array}{l}\text { Fin whale }(58.6) \text {, Sperm whale }(36.2) \\
\text { Fin whale }(51.7) \text {, Sperm whale }(38.4) \\
\text { Sperm whale }(38.6) \text {, Fin whale }(20.2) \text {, Minke whale (14.7), Pilot whale (13.0), } \\
\text { Risso's dolphin }(5.4) \\
\text { Fin whale }(43.9) \text {, Sperm whale }(24.5) \text {, Pilot whale }(22.7)\end{array}$ \\
\hline Northeast Shelf & $\begin{array}{l}\text { Winter } \\
\text { Spring } \\
\text { Summer } \\
\text { Autumn }\end{array}$ & $\begin{array}{l}\text { Fin whale }(63.0) \text {, Sperm whale }(16.8) \text {, Sei whale }(9.3) \\
\text { Fin whale }(46.5) \text {, Minke whale }(18.7) \text {, Sperm whale }(10.1) \text {, Sei whale }(8.6) \\
\text { Fin whale }(64.3) \text {, Sperm whale }(9.2) \text {, Minke whale }(7.8) \text {, Humpback whale }(6.2) \\
\text { Fin whale }(51.1) \text {, Minke whale }(14.3) \text {, Pilot whale }(7.1) \text {, } \\
\text { Humpback whale }(6.8) \text {, Sei whale }(5.8) \text {, Sperm whale }(5.4)\end{array}$ \\
\hline
\end{tabular}


Fin whales were strongly dominant in nearly every individual region and season, in fact, in 13 of 16 instances (Table 4). The exceptions were GOM/winter, when white-sided dolphins were the dominant species, GBK/autumn when humpback and sei whales were co-dominant, and MAB/summer when sperm whales were dominant. Eleven of the eighteen species included in this study comprised at least $5 \%$ of the cetacean standing stock in at least one region/season.

\section{Prey consumption}

Over the course of a year, whales and dolphins consumed 1.87 million tons of prey within the Northeast Shelf system (Table 5). This total included approximately 1.3 million tons of finfish
(68.9\% of the total), 337000 tons of squid (18.0\%), and 244000 tons of zooplankton (13.0\%). Consumption, like abundance, varied by region and season, and additionally by prey type. Fish were the dominant cetacean prey in nearly all regions and seasons, except for MAB in the summer and autumn, when squid was the prey consumed in the largest amount. Consumption of zooplankton by cetaceans was relatively low except in spring and summer in GOM and throughout the year in GBK. For the entire area, $40.7 \%$ of cetacean consumption was during the spring, followed by summer with $33.4 \%$, autumn with $16.4 \%$, and winter with $9.5 \%$. Comparing regions, total consumption was substantially higher in the two northern areas. Cetacean consumption in GOM and GBK

TABLE 5. Estimated consumption of prey (tons) by cetaceans in four regions (see text for definitions) of the USA Northeast shelf.

\begin{tabular}{|c|c|c|c|c|c|}
\hline Region & Season & Fish & Squid & Zooplankton & Total \\
\hline \multirow{5}{*}{ GOM } & Winter & 5808 & 767 & 0 & 6575 \\
\hline & Spring & 156780 & 3081 & 33382 & 193243 \\
\hline & Summer & 265988 & 2771 & 39534 & 308293 \\
\hline & Autumn & 118249 & 3001 & 8428 & 129678 \\
\hline & Total & 546825 & 9620 & 81344 & 637789 \\
\hline \multirow[t]{5}{*}{ GBK } & Winter & 35077 & 10627 & 17694 & 63398 \\
\hline & Spring & 191002 & 33991 & 78912 & 303905 \\
\hline & Summer & 65013 & 40981 & 13318 & 119312 \\
\hline & Autumn & 40485 & 14475 & 16969 & 81929 \\
\hline & Total & 331577 & 100074 & 126893 & 558544 \\
\hline \multirow[t]{5}{*}{ SNE } & Winter & 42658 & 7760 & 3275 & 53693 \\
\hline & Spring & 94703 & 25595 & 8833 & 129131 \\
\hline & Summer & 93998 & 34300 & 9611 & 137909 \\
\hline & Autumn & 24406 & 9909 & 2038 & 36353 \\
\hline & Total & 255765 & 77564 & 23757 & 357086 \\
\hline \multirow[t]{5}{*}{ MAB } & Winter & 30774 & 20280 & 2468 & 53522 \\
\hline & Spring & 71360 & 57417 & 5952 & 134729 \\
\hline & Summer & 24761 & 32950 & 1170 & 58881 \\
\hline & Autumn & 27718 & 39580 & 1956 & 69254 \\
\hline & Total & 154613 & 150227 & 11546 & 316386 \\
\hline \multirow[t]{5}{*}{ Northeast Shelf } & Winter & 114317 & 39434 & 23437 & 177188 \\
\hline & Spring & 513845 & 120084 & 127079 & 761008 \\
\hline & Summer & 449760 & 111002 & 63633 & 624395 \\
\hline & Autumn & 210858 & 66965 & 29391 & 307214 \\
\hline & Total & 1288780 & 337485 & 243540 & 1869805 \\
\hline
\end{tabular}


represented $34.1 \%$ and $29.9 \%$, respectively, of the Northeast Shelf total, while only $19.1 \%$ of the total consumption occurred in SNE, and $16.9 \%$ in MAB.

\section{Primary production required}

Based on the estimates of prey consumed by cetaceans in our food chain model, the amounts of phytoplankton primary production channeled to

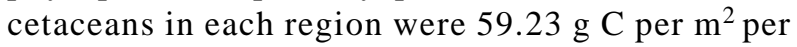
$\mathrm{yr}$ in GOM, 51.86 in GBK, 39.02 in SNE, and 39.14 in $\mathrm{MAB}$ (the area-weighted mean was 47.46 ; $\mathrm{SD}=$ 8.68). Average annual phytoplankton production levels in the four regions reported by O'Reilly and

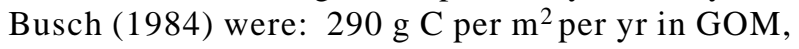
379 in GBK, 301 in SNE, and 334 in MAB. The percentages of total annual primary production channeled to the cetaceans of the four Northeast Shelf regions were: $20.4 \%$ in GOM, $13.7 \%$ in GBK, $13.0 \%$ in SNE, and $11.7 \%$ in MAB (the mean was $14.8 \%$; $\mathrm{SD}=3.4$ ).

\section{Discussion}

\section{Abundance and standing stock}

These results tended to be somewhat different than previous estimates based on the same survey data reported by CETAP (1982), Scott et al. (MS 1983), or Kenney et al. (1985). The differences can be accounted for by differences in the computation methods. For example, in the first two studies only the estimates for fin, humpback and right whales included a correction for diving, while Kenney et al. (1985) included no dive corrections. In none of the previous analyses were the unidentified sightings assigned to particular species. In all three of them the estimates for minke whales and harbor porpoises were seriously biased. We feel that including those factors has resulted in the best currently available estimates of abundance for the overall cetacean community. Unfortunately, there are no other comparable abundance estimates for the entire Northeast Shelf which might be useful for comparison or verification. The harbor porpoise surveys and other recent surveys by NMFS have covered only a relatively small subset of the CETAP study area and were limited to summer (Blaylock et al., 1995), and although these data were useful for improving estimates of minke whales and harbor porpoises, the areas and seasons surveyed were too limited to provide critical comparisons for other species.

This study incorporated the estimated abundances from the unidentified sightings, into the appropriate species based on proportions of identified sightings. It is likely that there were some errors in these assignments, but attempting to discriminate on any finer basis would have reduced the process to little more than "educated guessing" on each individual sighting. Not including the unidentified sightings at all would have introduced a much more significant bias.

Utilizing the minke whale and harbor porpoise data from the NMFS surveys to estimate an aerial survey bias factor has made our estimates of those two species much more realistic. The correction factors, 9.3 for harbor porpoise and 10.6 for minke whales, are similar to the value of 7.1 calculated from the estimate by Kraus et al. (1983), that aerial observers detected only $14 \%$ of porpoises seen by shore-based observers. The fact that the peak abundance estimate for harbor porpoise for the study area (49 420 in the spring) differs by less than 5\% from the NMFS estimate of 47200 for the population, indicates that the corrections resulted in realistic estimates. Including that change made both species, especially minke whales, much more significant components of the cetacean community than in the Scott et al. (MS 1983) analysis. It is possible that some errors would have been introduced here if there had been drastic distributional changes in either or both species between 1979-81 and 1991-92. For example, large differences between the 1991 and 1992 estimates of harbor porpoise in the NMFS study were believed to be due to distributional shifts in response to oceanographic conditions (Blaylock et al., 1995).

By applying a dive correction to all large whale species, this study eliminated the serious bias in Scott et al. (MS 1983) introduced by correcting the estimates for only fin, humpback and right whales. Using the dive correction, however, may have biased the right whale estimates on to the high side. Kenney et al. (1995) suggested that using a correction based on diving data from individual right whales would produce overestimates, because right whales tend to occur in large aggregations, and because the aerial surveys typically circle right whale sightings for extended periods of time to obtain identification photographs of individuals. Therefore, when a single right whale is sighted, it increases the likelihood of detecting other right whales in the vicinity as they surface while the plane is circling. The estimate of right whales was 393 during the spring, but Knowlton et al. (1994) estimated the population at 295 as of the end of 
1992. However, given the low numbers of right whales, the impact on the final consumption estimates would be relatively small, and it would only impact the zooplankton consumption estimates. Since humpback and fin whales are not individually identified from aerial photos and therefore not routinely circled, this bias is much less likely for those species. It is likely that correction factors estimated directly for long-diving species such as sperm whales and beaked whales might be markedly higher than the fin whale factor which was applied, however we lack data to justify using any other value. For most of the smaller toothed whales, there is probably little bias introduced by not using any dive correction factor. These species dive for shorter times than large whales and often occur in moderate to large herds, which are visually conspicuous at relatively long distances to aerial observers. The dive correction factors for these species, if at all necessary, would be substantially smaller than the smallest large whale factor.

\section{Prey consumption}

Whales, dolphins and porpoises of the Northeast Shelf annually consume about 1.28 million tons of fish, 337000 tons of squid and 244000 tons of zooplankton, for a total of 1.87 million tons. These estimates are substantially higher that those of Kenney et al. (1985) (276 000 tons fish, 244000 tons squid, 45000 tons zooplankton, and a total of 555000 tons). That study did not include dive correction factors for any species or scale for active metabolism. The results of the present study are similar to, but more reliable than, the total consumption estimates by Scott et al. (MS 1983) (1.25 million tons fish, 318000 tons squid, 174000 tons zooplankton, and 1.74 million tons total), who used dive correction factors only for fin, humpback and right whales, used many higher body weights based on the limited data available at the time, used under-estimates of minke whale and harbor porpoise abundance, and assumed each species to be exclusively piscivorous, teuthivorous or planktivorous in the absence of better information.

Sissenwine (1986) estimated that cetaceans consumed 5.4 tons per $\mathrm{km}^{2}$ of fish and squid on Georges Bank, using the Scott et al. (MS 1983) results as input data. Our results show total fish and squid consumption on Georges Bank as 432000 tons, or 6.3 tons per $\mathrm{km}^{2}$. The difference may be primarily due to the larger, corrected abundances of minke whales and harbor porpoises and the use of a dive correction factor for sperm whales in our estimates. Overholtz et al. (1991) estimated that marine mammals consumed a total of 120000 tons of fish annually from the Northeast Shelf, which is less than $10 \%$ of our estimated fish consumption. However, their estimate was based on a computer model including nine cetacean species and harbor seals feeding on four species of pelagic fishes (herring, mackerel, sand lance and silver hake). Their objective was not to realistically model cetacean predation, but to explore the impacts of different management schemes on pelagic fish populations.

How does cetacean predation on living resources of the Northeast Shelf compare to commercial fishery harvests? There is no relevant comparison for zooplankton which are not harvested by commercial fisheries. However, for fish and squid the cetacean predation was larger than commercial fishery harvests. Sherman et al. (1988) reported that total annual fish and squid landings from the Northeast Shelf ecosystem averaged 900000 tons between 1969 and 1978 with a peak catch of 1.2 million tons in 1974, and recorded an average 470000 tons per yr from 1979 on with an estimated maximum sustainable yield of 950000 tons. Our estimate for total fish and squid consumption by cetaceans, 1.63 million tons, was larger than all of those landings totals by 1.4 times the 1974 peak landings, 1.7 times the estimated maximum sustainable yield, 1.8 times the 1969-78 average, and 3.5 times the post-1979 average. For comparison, Sissenwine (1986) estimated that cetacean consumption on Georges Bank was $88.5 \%$ of the fishery catch. For squid alone, NMFS (1994) reported total Atlantic coast squid landings of 32000 tons in 1990, 39000 tons in 1991, 45000 tons in 1992, and 51000 tons in 1993. Our estimated cetacean consumption of squid was 6.6 times the 1993 harvest.

There are other marine ecosystems where cetacean consumption (or consumption by all marine mammals) has been estimated to be extremely large or to approach or exceed fishery harvests. Laevastu and Larkins (1981) estimated marine mammal predation in the Bering Sea to remove 2.66 million tons of fish, 2.98 million tons of squid, and 2.01 million tons of zooplankton. Laws (1977) estimated very large predation rates by Southern Ocean marine mammals for both prior to 20th Century industrial whaling (190 million tons krill, 12 million tons squid, 4 million tons fish) and after depletion of whale stocks (43 million tons krill, 5 million tons 
squid, 1 million ton fish). Both the Bering Sea and Southern are much larger in geographic extent than the Northeast Shelf, accounting for the substantially larger cetacean consumption totals. Bax (1991) summarized several studies comparing relative proportions of total fish consumption by marine mammals and commercial fisheries in six marine ecosystems including Georges Bank (using data from Sissenwine, 1986). The data presented show marine mammal consumption was estimated to be $167 \%$ of fishery harvests in the Barents Sea, $163 \%$ in the Benguela Current system, $107 \%$ in the eastern Bering Sea, $89 \%$ in Georges Bank, $2 \%$ in the North Sea and $0 \%$ in Balsfjorden. Our estimate that cetaceans consumed $346 \%$ of the average post-1979 fishery catches from the Northeast Shelf exceeds all of these, however, it is recognized that these recent fisheries are substantially depleted. Expressed as $171 \%$ of the estimated MSY, it seems to fit well with the data from the Barents Sea and Benguela Current systems. In another comparison, the predation by minke whales alone in the Northeastern Atlantic has been estimated by two different methods to exceed 1 million tons, and to equal or exceed commercial harvests of some fish stocks (Markussen et al., 1992; Nordøy et al., 1995).

Our consumption estimates were conservative, consistently using lower values in the computations when there was any question or choice (as in the selection of factors of 2.5 to scale from basal to active metabolism and 1.2 to correct mysticete feeding rates for migratory fasting). In comparison, a three-month migratory fast yielded a correction of 1.33 and a four-month fast yielded 1.5. Lockyer (1986) estimated that North Atlantic fin whales consumed $90 \%$ of their annual total within a five-month period, which resulted in a multiplicative factor of 2.16 during the peak feeding period.

The metabolic models used here scale for activity, but not for growth and reproduction. Reproduction, particularly lactation, is a major energy cost for cetaceans. Yasui and Gaskin (1986) estimated in the harbor porpoise that the additional cost of pregnancy and lactation represented $38-42 \%$ of total requirement for maintenance and activity, while Lockyer (1978, 1981a, b, 1986) has estimated the additional cost of reproduction in large baleen whales to be $20-25 \%$ of their usual metabolic requirements. Bernard and Hohn (1989) have also shown that the differential costs of pregnancy and lactation in spotted dolphins led to different feed- ing strategies in pregnant versus lactating females; lactating females tended to have fuller stomachs which contained significantly higher proportions of flying fish (higher energy density) than squid. These data demonstrate that any increase in consumption estimates to account for reproduction would only need to consider reproductively active females, the factors would be substantially lower than the percentages given above, and so are not likely to have a serious bias in our estimates.

\section{Primary production required}

When estimates of prey consumption by cetaceans in the trophic model of this study are used it suggests that cetaceans require $14.8 \%$ of the total phytoplankton primary production. This is lower than the $24.9 \%$ average primary production required (PPR) estimated by Scott et al. (MS 1983) from slightly smaller estimates of total prey consumption. The regional patterns reported by Scott $e t$ al. (MS 1983) were also different (GOM - 15.4\%, GBK $-25.5 \%$, SNE - 31.0\%, MAB - 27.8\%). These differences can be accounted for by different trophic level (TL) values for squid in the food chain models. We used TL $=3.2$ for squid, rather than the 4.0 value used by Scott et al. (MS 1983), and it had the effect of reducing the PPR for teuthivores (squid consumers) by $84 \%$. Teuthivorous cetaceans occur primarily along the shelf break (CETAP, 1982; Hain et al., 1985; Kenney and Winn, 1986), and there is no shelf break in the Gulf of Maine region, which explains why our estimate of PPR for GOM was the highest regional value, while it was the lowest value in the Scott et al. (MS 1983) estimates. On the other hand, a value similar to our $14.8 \%$ mean was reported by Huntley et al. (1991), and they estimated that an average of $12 \%$ (maximum $22.5 \%$ ) of carbon fixed by phytoplankton was recycled to the atmosphere by the breathing activities of marine mammals and seabirds. In different geographic areas, Pauly and Christenson (1995) estimated the mean PPR for fishery harvests in non-tropical continental shelf systems at $35.3 \%$. Our estimated mean PPR is less than half of their value, even though cetacean predation may be more than three times the fishery catches in the Northeast Shelf. At first glance, it seems that something must be in error. However, closer scrutiny of energetics suggests the difference could be due to differences in mean trophic level between cetacean prey and commercial harvests. Pauly and Christenson (1995) estimated a mean TL value of 3.5 for non-tropical shelf fisheries. Our mean TL, weighted for amount of 
consumption of each prey type was 2.85 . The PPR for equal harvests of $\mathrm{TL}=3.5$ stocks versus $\mathrm{TL}=$ 2.85 stocks is greater by a factor of $4.47\left(10^{2.5} /\right.$ $10^{1.85}$ ). In short, cetacean predation has a lesser impact on primary production than commercial fishery harvests because commercial fishers "feed" higher on the food chain than whales and dolphins.

Our trophic model is conservative because of the TL values we have used, though this affects only the PPR estimates, not the consumption estimates. The zooplankton eaten by fin, humpback, and minke whales, as well as some proportion of that eaten by sei and right whales, are comprised of euphausiids rather than copepods. Krill would have $\mathrm{TL}=2.2$ rather than 2.0 (Pauly and Christensen, 1995). In addition, some proportion of fishes consumed by cetaceans are probably at least partly piscivorous rather than entirely planktivorous. Pauly and Christenson's (1995) estimates of TL values for possible cetacean prey include mackerel $(\mathrm{TL}=3.3-$ $3.4)$, mullet ( $\mathrm{TL}=3.8)$, gadids $(\mathrm{TL}=3.8)$, and jacks $(\mathrm{TL}=3.8)$.

\section{Conclusions}

The results clearly show that whales, dolphins and porpoises are significant predators in the Northeast Shelf ecosystem. Their annual consumption of fishery resources may represent an amount from approximately one-third to more than three times greater than the annual harvests by fisheries from the same system taking into account the variations in catches over the last $2-3$ decades. It is recognized these are estimates, however, such results are unlikely to be better than an approximation. These particularly relate to the obvious methodological difficulties of taking weights or metabolic rates of animals weighing many tons or developing precise estimates of abundance for cetaceans in areas as big as the Northeast Shelf. In addition, these animals are legally protected and cannot be sampled like fishes. Very few species have had long-term intensive studies, e.g. right whales (Knowlton et al., 1994) and bottlenose dolphins (Scott et al., 1990), which produced reliable information on parameters such as age structure, age at maturity, reproductive rates, and population growth rates.

A complicating factor in quantifying cetacean consumption is that many species may have changed in abundance since the 1979-81 CETAP surveys. The only species of the Northeast Shelf for which published trend data are available is the right whale.
Their population estimates show slow increasing rates at 2.5\% (Knowlton et al., 1994) and 3.8\% (Kenney et al., 1995), despite significant levels of anthropogenic mortality from ship strikes and fishing gear entanglements (Kraus, 1990; Kenney and Kraus, 1993) and suspected reproductive anomalies (Knowlton et al., 1994). For most of the other cetacean species the known anthropogenic mortality is not thought to be high enough to deplete populations (Blaylock et al., 1995), therefore it might be expected that many populations could be increasing. If 5\% annual increase rates are assumed, populations would have more than doubled since 197981. However, there are very little data on limiting factors on cetacean populations to justify any annual rate of increase. Since they are apex predators, at some point their populations would be limited by food resources, through intra- and inter-specific competition (Hairston et al., 1960; Hairston and Hairston, 1993).

Resource limitation of cetacean predators implies interspecific competition with other predators on the same resource(s). The other predators include the commercial fishing industry. This suggests that either cetaceans and fisheries presently compete, or will compete when cetacean populations grow large enough. Direct competition between cetaceans and fisheries is probably low, as cetaceans tend to prey on different species and/or age-classes and consume, on average, at a lower level on the food web. In the Northeast Shelf, there are no fisheries for copepods or euphausiids, and many of the squid species selected by cetaceans are similarly not harvested. At least some of the fish species eaten by cetaceans, however, may be important commercially, in particular herring and mackerel. So there may be competition between cetaceans and fisheries for these species, especially if cetaceans are selective in their predation. Sissenwine et al. (1984b) suggested that predation by cetaceans, especially fin whales, on Georges Bank herring stocks may have had a depensatory effect on the herring and significantly delayed herring recovery from depletion by overfishing. The model developed by Overholtz et al. (1991) showed that the type of feeding response by predators can significantly affect the population dynamics of prey fish populations. The level of competition between cetaceans and fisheries can also change with natural or anthropogenic shifts in fish stocks. Since the 1960s, there have been several shifts in dominance in Northeast Shelf pelagic fish stocks between herring (and mackerel) and sand lance (Sherman et al., 1981, 
1988; Sherman, 1986; Sissenwine, 1986; Fogarty et al., 1991). Cetacean predation on small pelagic fishes has also shifted in parallel, with concomitant changes in cetacean distribution patterns (Payne et al ., 1986, 1990; Schilling et al., 1992; Kenney et al., 1996). Cetacean predation on sand lance would represent a lower level of direct competition with fisheries than feeding on herring, since there is no significant fishery for sand lance in the Northeast Shelf ecosystem.

The effects of cetaceans on fisheries, or of fisheries on cetaceans, are not straightforward or easily predictable (Katona and Whitehead, 1988). Given the multiplicity of predator-prey linkages in the Northeast Shelf food web, the effects, both direct and indirect, of cetacean apex predation on important commercial fishery stocks are extremely complex. Reliable prediction of these effects on fisheries, if possible at all, will be extremely difficult and will require sophisticated multi-species models (May et al., 1979). The same is true for the other direction - effects of fisheries on cetacean populations. These can also be both indirect and significant. For example, an inshore shift in humpback whales in Newfoundland following the crash of offshore capelin stocks led to an increase in humpback entanglements and mortalities in inshore cod traps (Lien et al., 1979; Perkins and Beamish, 1979; Whitehead and Carscadden, 1985; Lien, 1994). Kenney et al. (1996) suggested a similar shift in Gulf of Maine harbor porpoise following collapse of the Georges Bank herring stock may have increased entanglements in the sink gillnet fishery. Unraveling all of the inter-connecting linkages and fully understanding these sorts of effects will require a great deal of research effort.

\section{Acknowledgements}

The Cetacean and Turtle Assessment Program (CETAP) was funded by the Bureau of Land Management (later Minerals Management Service), U.S. Department of the Interior. The efforts of the large number of individuals involved in the original data collection and processing are greatly appreciated. A literature review which provided many of the input data used was funded by the Northeast Fisheries Science Center, National Marine Fisheries Service, National Oceanic and Atmospheric Administration, U. S. Department of Commerce. Special thanks go to Ken Sherman and Jack Green for stimulating discussions and encouragement, to Marty Hyman and Ralph Owen for their assistance in the analyses, and to Mike Sissenwine and Tim Smith for critical reviews of draft manuscripts.

\section{References}

BARLOW, J., C. W. OLIVER, T. D. JACKSON, and B. L. TAYLOR. 1988. Harbor porpoise, Phocoena phocoena, abundance estimation for California, Oregon, and Washington: II. Aerial surveys. Fish. Bull., 86: 433-444.

BAX, N. J. 1991. A comparison of the fish biomass flow to fish, fisheries, and mammals in six marine ecosystems. ICES Mar. Sci. Sym., 193: 217-224.

BERNARD, H. J., and A. A. HOHN. 1989. Differences in feeding habits between pregnant and lactating spotted dolphins (Stenella attenuata). J. Mamm., 70: 211-215.

BLAYLOCK, R. A., J. H. W. HAIN, L. J. HANSEN, D. L. PALKA, and G. T. WARING. 1995. U.S. Atlantic and Gulf of Mexico Marine Mammal Stock Assessments. NOAA Tech. Mem. NMFS-SEFC-363.

BRODIE, P. F. 1975. Cetacean energetics: an overview of intraspecific size variation. Ecology, 56: 152161.

CETACEAN AND TURTLE ASSESSMENT PROGRAM (CETAP). 1982. A Characterization of Marine Mammals and Turtles in the Mid- and North-Atlantic Areas of the U.S. Outer Continental Shelf, Final Report. Contract No. AA551-CT8-48. U.S. Department of the Interior, Bureau of Land Management, Washington, DC, $586 \mathrm{p}$.

CLARK, A., and P. A. PRINCE. 1980. Chemical composition and caloric value of food fed to mollymauk chicks Diomedea melanophris and D. chrysostoma at Bird Island, South Georgia. Ibis, 122: 488-494.

COHEN, E. B., M. D. GROSSLEIN, M. P. SISSENWINE, F. STEIMLE, and W. R. WRIGHT. 1982. Energy budget of Georges Bank. Can. Spec. Pub. Fish. Aquat. Sci.. 59: 95-107.

CROXALL, J. P., and P. A. PRINCE. 1982. Caloric content of squid (Mollusca: Cephalopoda). Brit. Antarc. Surv. Bull., 55: 27-32.

EVANS, P. G. H. 1987. The Natural History of Whales and Dolphins. Facts on File, New York, 343 p.

FAIRFIELD, C. P., G. T. WARING, and M. H. SANO. 1993. Pilot whales incidentally taken during the distant water fleet Atlantic mackerel fishery in the midAtlantic Bight, 1984-1988. Rep. Int. Whal. Comm., Special Issue, 14: 107-117.

FOGARTY, M. J., E. B. COHEN, W. L. MICHAELS, and W. W. MORSE. 1991. Predation and the regulation of sand lance populations: an exploratory analysis. ICES Mar. Sci. Sym., 193: 120-124.

GASKIN, D. E. 1982. The Ecology of Whales and Dolphins. Heinemann Educational Books Ltd., London, $459 \mathrm{p}$.

HAIN, J. H. W., M. A. M. HYMAN, R. D. KENNEY, and H. E. WINN. 1985. The role of cetaceans in the shelf edge region of the northeastern United States. Mar. Fish. Rev., 47(1): 13-17. 
HAIRSTON, N. G. and N. G. HAIRSTON. 1993. Causeeffect relationships in energy flow, trophic structure, and interspecific interactions. Am. Nat., 142: 379-411.

HAIRSTON, N. G., F. E. SMITH, and L. B. SLOBODKIN. 1960. Community struture, population control, and competition. Am. Nat., 94: 421-425.

HINGA, K. R. 1979. The food requirements of whales in the Southern Hemisphere. Deep-Sea Res., 26: $569-577$.

HUNTLEY, M. E., M. D. G. LOPEZ, and D.M. KARL. 1991. Top predators in the Southern Ocean: a major leak in the biological carbon pump. Science, 253: 64-66.

JEFFERSON, T. A., S. LEATHERWOOD, and M. A. WEBBER. 1993. Marine Mammals of the World. Food and Agriculture Organization of the United Nations, Rome, 320 p.

KATONA, S., and H. WHITEHEAD. 1988. Are Cetacea ecologically important? Oceanogr. Mar. Biol. Ann. Rev., 26: 553-568.

KENNEY, R. D., M. A. M. HYMAN, and H. E. WINN. 1985. Calculation of Standing Stocks and Energetic Requirements of the Cetaceans of the Northeast United States Outer Continental Shelf. NOAA Tech. Mem. NMFS-F/NEC-41.

KENNEY, R. D., and S. D. KRAUS. 1993. Right whale mortality: a correction and an update. Mar. Mamm. Sci., 9: 445-446.

KENNEY, R. D., P. M. PAYNE, D. W. HEINEMANN, and H. E. WINN. 1996. Shifts in Northeast Shelf cetacean distributions relative to trends in Gulf of Maine/Georges Bank finfish abundance. In: The Northeast Shelf Ecosystem: Assessment, Sustainability, and Management. K. Sherman, N. A. Jaworski, and T. J. Smayda (eds.), Blackwell Scientific Publications, Cambridge, MA, p. 169-196.

KENNEY, R. D., and H. E. WINN. 1986. Cetacean highuse habitats of the northeast United States continental shelf. Fish. Bull., 84: 345-357.

KENNEY, R. D., H. E. WINN, and M. C. MACAULAY. 1995. Cetaceans in the Great South Channel, 19791989: Right whale (Eubalaena glacialis). Cont. Shelf. Res., 15: 385-414.

KLEIBER, M. 1975. The Fire of Life, An Introduction to Animal Energetics. R.E. Kreiger Publishing Co., Huntington, NY, 453 p.

KNOWLTON, A. R., S. D. KRAUS, and R. D. KENNEY. 1994. Reproduction in North Atlantic right whales. Can. J. Zool., 72: 1297-1305.

KRAUS, S. D. 1990. Rates and potential causes of mortality in North Atlantic right whales. Mar. Mamm. Sci., 6: 278-291.

KRAUS, S. D., J. R. GILBERT, and J. H. PRESCOTT. 1983. A comparison of aerial, shipboard, and landbased survey methodology for the harbor porpoise, Phocoena phocoena. Fish. Bull., 81: 910-913.

LAEVASTU, T., and H. A. LARKINS. 1981. Marine Fisheries Ecosystem, Its Quantitative Evaluation in
Management. Fishing News Books, Farnham, Surrey, $167 \mathrm{p}$.

LAWS, R. M. 1977. Seals and whales of the Southern Ocean. Phil. Trans. R. Soc. London, B, Biol. Sci., 279: 81-96.

LIEN, J. 1994. Entrapments of large cetaceans in passive inshore fishing gear in Newfoundland and Labrador (1979-1990). Rep. Int. Whal. Comm., Special Issue, 15: 149-157.

LIEN, J., S. JOHNSON, and B. MERDSOY. 1979. Whale distribution in Newfoundland during 1979. Osprey, 11(2): 21-32.

LOCKYER, C. 1978. A theoretical approach to the balance between growth and food consumption in the fin and sei whales, with special reference to the female reproductive cycle. Rep. Int. Whal. Comm., 28: 243-249.

LOCKYER, C. 1981a. Estimation of the energy costs of growth, maintenance, and reproduction in the female minke whale (Balaenoptera acutorostrata), from the Southern Hemisphere. Rep. Int. Whal. Comm., 31: 337-343.

LOCKYER, C. 1981b. Growth and energy budgets of large baleen whales from the Southern Hemisphere. In: Mammals in the Sea, Vol. III, General Papers and Large Cetaceans. FAO, Rome, p. 379-487.

LOCKYER, C. 1986. Body fat condition in North Atlantic fin whales, Balaenoptera physalus, and its relationship with reproduction and food resource. Can. J. Fish. Aquat. Sci., 43: 142-147.

MACKINTOSH, N. A. 1966. The distribution of southern blue and fin whales. In: Whales, Dolphins, and Porpoises. K. S. Norris (ed.), University of California Press, Berkeley, CA. p. 125-144

MARKUSSEN, N. H., M. RYG, and C. LYDERSEN. 1992. Food consumption of the NE Atlantic minke whale (Balaenoptera acutorostrata) population estimated with a simulation model. ICES J. Mar. Sci., 49: 317-323.

MATTHEWS, L. H. 1978. The Natural History of the Whale. Columbia University Press, New York, 219 p.

MAY, R. M., J. R. BEDDINGTON, C. W. CLARK, S. J. HOLT, and R. J. LAWS. 1979. Management of multispecies fisheries. Science, 205: 267-277.

NATIONAL MARINE FISHERIES SERVICE (NMFS). 1994. Fisheries of the United States, 1993. Current Fishery Statistics No. 9300. U.S Department of Commerce, National Oceanic and Atmospheric Administration, National Marine Fisheries Service, Silver Spring, MD, $121 \mathrm{p}$.

NEMOTO, T. 1970. Feeding patterns of baleen whales in the oceans. In: Marine Food Chains. J. H. Steele (ed.), Univ. of California Press, Berkeley, CA, p. 241-252.

NORD ØY, E. S., L. P. FALKOW, P.-E. MÅRTENSSON, and A. S. BLIX. 1995. Food requirements of Northeast Atlantic minke whales. In: Whales, Seals, Fish and Man. A. S. Blix, L. Walløe, and $\varnothing$. Ulltang (eds.), Elsevier Science, Amsterdam, p. 307-317. 
O'REILLY, J. E., and D. A. BUSCH. 1984. Phytoplankton primary production on the northwestern Atlantic shelf. ICES Rapp. Proc.-Verb., 183: 255-268.

OVERHOLTZ, W. J., S. A. MURAWSKI, and K. L. FOSTER. 1991. Impact of predatory fish, marine mammals, and seabirds on the pelagic fish ecosystem of the northeastern USA. ICES Mar. Sci. Sym., 193: $198-208$.

OVERHOLTZ, W.J., and G.T WARING. 1991. Diet composition of pilot whales Globicephala sp. and common dolphins Delphinus delphis in the Mid-Atlantic Bight during spring 1989. Fish. Bull., 89: 723-728.

PALKA, D.L. 1995. Abundance estimate of the Gulf of Maine harbor porpoise. Rep. Int. Whal. Comm., Special Issue, 16: 27-50.

PAULY, D., and V. CHRISTENSEN. 1995. Primary production required to sustain global fisheries. Nature, 374: $255-257$.

PAYNE, P. M., J. R. NICOLAS, L. O'BRIEN, and K. D. POWERS. 1986. The distribution of the humpback whale Megaptera novaeangliae on Georges Bank and in the Gulf of Maine in relation to densities of the sand eel Ammodytes americanus. Fish. Bull., 88: $687-696$.

PAYNE, P. M., D. N. WILEY, S. B, YOUNG, S. PITTMAN, P. J. CLAPHAM, and J. W. JOSSI. 1990. Recent fluctuations in the abundance of baleen whales in the southern Gulf of Maine in relation to changes in selected prey. Fish. Bull., 88: 687-696.

PERKINS, J. S., and P. C. BEAMISH. 1979. Net entanglements of baleen whales in the inshore fishery of Newfoundland. J. Fish. Res. Board Can., 36: $512-528$.

PLATT, T. 1969. The concept of energy efficiency in primary production. Limnol. Oceanogr., 14: 653659.

SCHILLING, M. R., I. SEIPT, M. T. WEINRICH, S. E. FROHOCK, A. E. KUHLBERG, and P. J. CLAPHAM. 1992. Behavior of individually-identified sei whales Balaenoptera borealis during an episodic influx into the Gulf of Maine in 1986. Fish. Bull., 90: 749-755.

SCOTT, G. P., R. D. KENNEY, T. J. THOMPSON, and H. E. WINN. MS 1983. Functional roles and ecological impacts of the cetacean community in the waters of the northeastern U.S. continental shelf. ICES C.M. Doc., No. N:12, 32 p.

SCOTT, M. D., R. S. WELLS, and A. B. IRVINE. 1990. A long-term study of bottlenose dolphins on the West Coast of Florida. In: The Bottlenose Dolphin. S. Leatherwood and R.R. Reeves (eds.), Academic Press, San Diego, CA, p. 235-244.

SHERMAN, K. 1980. MARMAP, a fisheries ecosystem study in the northwest Atlantic: fluctuations in ichthyoplankton-zooplankton components and their potential for impact on the system. In: Advanced Concepts in Ocean Measurements for Marine Biology. F. P. Diemer, F. J. Vernberg, and D. Z. Mierkes (eds.), University of South Carolina Press, Charles- ton, SC, p. 9-37.

SHERMAN, K. 1986. Measurement strategies for monitoring and forecasting variability in large marine ecosystems. In: Variability and Management of Large Marine Ecosystems. K. Sherman and L. M. Alexander (eds.), AAAS Selected Symposia No. 99, Westview Press, Boulder, CO, p. 203-236.

SHERMAN, K., and L. M. ALEXANDER (eds.) 1986. Variability and Management of Large Marine Ecosystems. AAAS Selected Symposia No. 99, Westview Press, Boulder, CO, 319 p.

1989. Biomass Yields and Geography of Large Marine Ecosystems. AAAS Selected Symposia No. 111, Westview Press, Boulder, CO, 493 p.

SHERMAN, K., L. M. ALEXANDER, and B. D. GOLD (eds.) 1990. Large Marine Ecosystems: Patterns, Processes, and Yields. Publ. No. 90-30S, American Association for the Advancement of Science, Washington, DC, $242 \mathrm{p}$.

1991. Food Chains, Yields, Models, and Management of Large Marine Ecosystems. Westview Press, Boulder, CO, 320 p.

1993. Stress, Mitigation, and Sustainability of Large Marine Ecosystems. AAAS Press, Washington, DC, $376 \mathrm{p}$.

SHERMAN, K., J. R. GREEN, J. R. GOULET, and L. EJYSMONT. 1982. Coherence in zooplankton of a large northwest Atlantic ecosystem. Fish. Bull., 81: 855-862.

SHERMAN, K., M. GROSSLEIN, D. MOUNTAIN, D. BUSCH, J. O'REILLY, and R. THEROUX. 1988. The continental shelf ecosystem off the northeast coast of the United States. In: Ecosystems of the World 27: Continental Shelves. H. Postema and J. J. Zijlstra (eds.), Elsevier Press, Amsterdam, p. 279-337.

SHERMAN, K., N. A. JAWORSKI, and T. J. SMAYDA (eds.) 1996. The Northeast Shelf Ecosystem: Assessment, Sustainability, and Management. Blackwell Scientific Publications, Cambridge, MA, $564 \mathrm{p}$.

SHERMAN, K., C. JONES, L. SULLIVAN, W. SMITH, P. BERRIEN, and L. EJSYMONT. 1981. Congruent shifts in sand eel abundance in western and eastern North Atlantic ecosystems. Nature, 291: 486-489.

SISSENWINE, M. P. 1986. Perturbation of a predatorcontrolled continental shelf ecosystem. In: Variability and Management of Large Marine Ecosystems. K. Sherman and L. M. Alexander (eds.), AAAS Selected Symposia No. 99, Westview Press, Boulder, CO, p. 55-85.

SISSENWINE, M. P., E. B. COHEN, and M. D. GROSSLEIN. 1984a. Structure of the Georges Bank ecosystem. ICES Rapp. Proc.-Verb., 183: 243-254.

SISSENWINE, M. P., W. J. OVERHOLTZ, and S. H. CLARK. 1984b. In search of density dependence. In: Proceedings of the Workshop on Biological Interactions Among Marine Mammals and Commercial Fisheries in the Southeastern Bering Sea. 
B. R. Melteff (ed.). Alaska Sea Grant Report 84-1, Alaska Sea Grant College Program, University of Alaska, Fairbanks, AK, p. 119-137.

WARING, G. T., P. GERRIOR, P. M. PAYNE, B. L. BARRY, and J. R. NICOLAS. 1990. Incidental take of marine mammals in foreign fishery activities off the northeast United States, 1977-1988. Fish. Bull.,
88: $347-360$.

WHITEHEAD, H. and J. CARSCADDEN. 1985. Predicting inshore whale abundance - whales and capelin off the Newfoundland coast. Can. J. Fish. Aquat. Sci., 42: 976-981.

YASUI, W. Y., and D. E. GASKIN. 1986. Energy budget of a small cetacean. Ophelia, 25: 183-197. 